\section{Royal Society Research Appointments}

DR. J. S. GrLlespie, of the Department of Physiology, University of Glasgow, has been appointed the first Sophie Fricke Royal Society research fellow in the Rockefeller Institute, where he will work on intracellular recording from innervated smooth muscle. This appointment is a new post which has been established by the Rockefeller Institute from funds left to the Institute by the late Miss Sophie D. Fricke of New York City, who died on March 1, 1958. The trustees of the Rockefeller Institute have authorized use of the income from the fund for the triple purposes of fostering international understanding, training scientists of exceptional promise and supporting significant research. It is the intention of the Rockefeller Institute to appoint four research fellows each year, from France, Denmark, Sweden and the United Kingdom, the selection being made by the French Academy of Sciences, the Royal Danish Academy of Sciences and Letters, the Swedish Royal Academy of Sciences and the Royal Society.

A Locke research fellowship has been awarded to Dr. B. G. Cragg, of the Department of Anatomy, University College, London, to work at University College, London, on the connexion and physiological functions of certain nuclei in the brain. Stothert research fellowships have been awarded to: Mr. W.D. Butt, of the Department of Biological Chemistry, University of Aberdeen, to work at the Molteno Institute of Biology and Parasitology, University of Cambridge, on intracellular hæmoprotein compounds ; to Mr. R. A. Webster, of the Department of Pharmacology, University College, London, to work at University College, London, on the pharmacology of tetanus, and to Mr. J. A. Hunt, of Peterhouse, Cambridge, to work on the chemical structure of proteins.

\section{Leopoldina Academy: New Members}

Ix is announced that the following, with others, have been elected members of the German Leopoldina Academy of Natural Sciences, Halle : Mathematics Section, Profs. Herbert C. Grötzsch (Halle) and Hans Schubert (Halle); Physics Section, Prof. Otto Kratky (Graz); Geophysics and Meteorology Section, Prof. Erik Herbert Palmén (Helsinki) ; Chemistry Section, Profs. Günther Rienäcker (Berlin) and Wilhelm Treibs (Leipzig); Botany Section, Profs. James Bonner (Calif.), William O. James (London) and P. Maheshwari (Delhi); Zoology Section, Profs. A. W. Iwanow (Leningrad), E. N. Pawlowsky (Leningrad) and Fritz Peus (Berlin) ; and Geography Section, Profs. Rudolf Käubler (Halle) and Ernst Neef (Leipzig).

University News:

London

Prof. W. R. Niblett, director of the Institute of Education, University of Leeds, has been appointed dean of the University of London Institute of Education with the title of professor of education in the University.

The following appointments to University readerships have been announced: Dr. D. J. Anderson (physiology in relation to dentistry), tenable at Guy's Hospital Medical School; Dr. A. Ashmore (experimental physics), tenable at Queen Mary College; Dr. F. Hobbiger (pharmacology), tenable at Middlesex Hospital Medical School; Dr. M. B. Shapiro (psychology), tenable at the Institute of Psychiatry;
J. W. Stewart (hæmatology), tenable at Middlesex Hospital Medical School; Dr. D. F. Cheesman (biochemistry), in respect of his post at Bedford College; Dr. A. P. Millman (mining geology), in respect of his post at the Imperial College of Science and Technology.

Southampton

THe University has conferred upon Prof. P. Ford, professor and dean of economics, who is retiring on September 30, the title of professor emeritus. Prof. Ford will formally open the newly completed building for the Faculty of Economics and the Ford Collection of Parliamentary Papers on October 14. Mr. R. G. Woods, of the University Library, Cambridge, has been appointed deputy librarian. The title of senior lecturer has been conferred upon Dr. G. W. A. Fowles (Chemistry), Dr. J. P. Jones (Aeronautical Engineering) and Dr. R. A. Pelham (Geography). The following lectureships are also announced: Dr. A. N. Clements (physiology and biochemistry); Dr. J. Heading (applied mathematics); Mr. R. W. Page (mechanical engineering); Dr. J. R. Rydzewski (civil engineering); Dr. R. G. Scurlock (physics); Dr. E. V. Vernon (electronics).

\section{Announcements}

Mr. J. B. Apams, at present director of the Proton-Synchrotron Group of the European Council for Nuclear Research near Geneva, has been appointed director of a new establishment to deal with controlled thermonuclear research. The work in this field now being done at Harwell, and some of the work now being done at the Atomic Weapons Research Establishment, Aldermaston, will be moved to this new establishment when its site has been chosen.

The Elmer A. Sperry Award "for outstanding achievement in the field of transportation" will be presented in 1959 to the de Havilland Aircraft Co., Ltd., the creators of the world's first jet passenger transport, the British-built Comet. Formal presentation of the award will take place in New York later this year at a joint meeting of the Institute of the Aeronautical Sciences and the Royal Aeronautical Society. The award is sponsored by four engineering societies: the American Society of Mechanical Engineers, the American Institute of Electrical Engineers, the Society of Automotive Engineers and the Society of Naval Architects and Marine Engineers.

AN international symposium on Algology will be held at the Indian Agricultural Research Institute, Pusa, New Delhi, during December 7-12, under the joint sponsorship of the Indian Council of Agricultural Research and Unesco. Main topics which will be discussed are nitrogen-fixing algae, edible algae and their mass culture. Further information can be obtained from the Unesco South Asia Science Co-operation Office, 21 Curzon Road, New Delhi, India.

Erratum. With reference to the communication entitled "A New Method for working up Processing Mixtures containing Anhydrous Aluminium Chloride" (Nature, July 11, p. 117), Dr. T. Széll states that a mistake was made in preparing the English translation: col. 2, line 1, for "20 ml." read " 25 ml.". 